\title{
Nodular Typhlitis Associated with the Nematodes Heterakis gallinarum and Heterakis isolonche in Pheasants: Frequency and Pathology with Evidence of Neoplasia
}

\author{
Rodrigo Caldas Menezes, Rogério Tortelly*, Delir Corrêa Gomes/ ${ }^{++}$, \\ Roberto Magalhães Pinto/ ${ }^{+} /+$
}

\begin{abstract}
Laboratório de Helmintos Parasitos de Vertebrados, Departamento de Helmintologia, Instituto Oswaldo Cruz-Fiocruz, Av. Brasil 43561, 21045-900 Rio de Janeiro, RJ, Brasil *Departamento de Patologia, Faculdade de Veterinária, Universidade Federal Fluminense, Niterói, RJ, Brasil
\end{abstract}

An investigation related to the frequency and pathology of Heterakis gallinarum and pathology of Heterakis isolonche in pheasants from Rio de Janeiro, Brazil was conducted by means of clinical examinations, necropsies, and histopathological analysis in 50 ring-necked pheasants from backyard flocks of 11 localities; also, histological sections of caeca of golden pheasants deposited in the Helminthological Collection of the Oswaldo Cruz Institute (CHIOC) have been considered in the present study. During necropsies, only specimens of $\mathrm{H}$. gallinarum were recovered with a prevalence of $90 \%$, mean intensity of 81.9 and range of infection of 1-413. Gross lesions were characterized by congestion, thickening, petechial haemorrhages of the mucosa, intussusception, and nodules in the cecal wall. Under microscopy, chronic difuse typhlitis, haemosiderosis, granulomas with necrotic center in the submucosa and leiomyomas in the submucosa, muscular and serosa associated with immature H. gallinarum worms were observed. The examination of histological sections previously deposited in the CHIOC, revealed more severe alterations associated with concomitant infections with $\mathrm{H}$. gallinarum and $\mathrm{H}$. isolonche in golden pheasants, and were characterized by several necrotic areas with cholesterol clefts in the submucosa, giant cell granulomas in the submucosa, and serosa centralized by necrosis and worm sections and neoplastic nodules in the muscular and subтисова.

Key words: nodular typhlitis - Heterakis gallinarum - Heterakis isolonche - pheasants - Phasianus colchicus - Brazil

The nodular or verrucous typhlitis is a fatal parasitary disease, occurring worldwide and mostly affecting pheasants of different species and is characterized by the formation of inflammatory or granulomatous and even neoplastic nodules located in the cecal wall, mainly in the submucosa due, principally, to the infection with the nematode Heterakis isolonche Linstow, 1906 (Schwartz 1924, Beaudette 1942, Julini \& Valenza 1975, Griner et al. 1977, Callinan 1987, Balaguer et al. 1992, Bhaskara Rao 1994). The nematode Heterakis gallinarum (Schrank, 1788) can frequently be found in the caeca of pheasants (Madsen 1941, Gilbertson \& Huggins 1964, Greiner 1972, Draycott et al. 2000) and although considered of low pathogenicity in single infections (Lund \& Chute 1974), previous studies report to a more severe pathology induced by this nematode in domestic Galliformes causing nodular typhlitis, with the formation of inflammatory or granulomatous cecal nodules (Meads \& Taylor 1963, Kaushik \& Sharma Deorani 1969, Riddel \& Gajadhar 1988, Khan et al. 1994).

${ }^{+}$Corresponding author. Fax: $+55-21-2598.4361$. E-mail: rmpinto@ioc.fiocruz.br

${ }^{++}$Research fellow CNPq

Received 17 July 2003

Accepted 22 October 2003
In Brazil, there is a single report of the occurrence of coinfection with $H$. isolonche and $H$. gallinarum and the appearance of verrucous typhlitis in ring-necked (Phasianus colchicus torquatus) and in golden (Chrysolophus pictus) pheasants from the Zoological Garden of Rio de Janeiro, with high mortality levels (Mendonça 1953). Nevertheless, there were no data on the pathology and frequency of these nematodes in the hosts, confirming the lack of information about this disease in our country.

The main target of this investigation was to evaluate the prevalence, mean intensity, and range of infection of H. gallinarum and the associated gross and microscopic lesions in ring-necked pheasants (Phasianus colchicus) from backyard flocks in Rio de Janeiro, Brazil, comparing the microscopic findings to those previously reported for H. isolonche.

\section{MATERIALS AND METHODS}

Fifty specimens of ring-necked pheasants (Phasianus colchicus L., 1758), 25 males, 25 females, weigh 200-750 g from backyard flocks of 11 localities of the state of Rio de Janeiro, Brazil, were investigated. The localities and number of examined hosts are, respectively: Niterói ( $22^{\circ} 53^{\prime}$ 'S- $\left.43^{\circ} 06^{\prime} \mathrm{W}\right)$ : 9; Rio de Janeiro ( $22^{\circ} 54^{\prime} \mathrm{S}-43^{\circ} 12^{\prime} \mathrm{W}$ ): 8; Tanguá $\left(22^{\circ} 73^{\prime}\right.$ 'S $\left.-42^{\circ} 71^{\prime} \mathrm{W}\right)$ : 9; São Francisco do Itabapoana $\left(21^{\circ} 28^{\prime} \mathrm{S}-41^{\circ} 08^{\prime} \mathrm{W}\right)$ : 8; Santo Antônio de

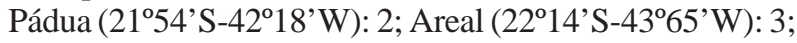
Petrópolis (22 $\left.30^{\prime} \mathrm{S}-43^{\circ} 10^{\prime} \mathrm{W}\right)$ : 2; São José do Vale do Rio

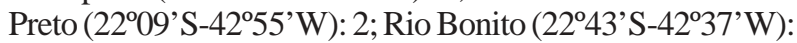
4; Engenheiro Paulo de Frontin ( $\left.22^{\circ} 32^{\prime} \mathrm{S}-43^{\circ} 40^{\prime} \mathrm{W}\right)$ : 2 ; Laje 
do Muriaé $\left(21^{\circ} 12^{\prime} \mathrm{S}-42^{\circ} 07^{\prime} \mathrm{W}\right)$ : 1 . After individual clinical evaluation birds were killed and submitted to necropsy, according to the technique of Zander et al. (1997).

Caeca were opened, with the aid of scissors, in Petri dishes containing $0.85 \% \mathrm{NaCl}$ solution. Nematodes were collected, rinsed in the same solution, fixed with hot AFA (alcohol $70^{\circ} \mathrm{GL}, 93 \mathrm{ml}$; formaldehyde, $5 \mathrm{ml}$; acetic acid, 2 $\mathrm{ml}$ ) and counted under a stereoscope microscope.

Nematodes were clarified in acetic acid and phenol and identified in accordance with Vicente et al. (1995). Some specimens were preserved in Canada balsam and deposited in the Helminthological Collection of the Oswaldo Cruz Institute (CHIOC) 36213, 36.214 a-c, $36215 \mathrm{a}-\mathrm{c}, 36216,36217,36218,36219$, and 36220 (whole mounts); slides $36214 \mathrm{~d}-\mathrm{f}, 36221$ and 36222 refer to histological sections. Fragments of the parasitized caeca were removed and immediately fixed in $10 \%$ formalin. The material was then routinely processed (Behmer et al. 1976) for parafin embedding. Five micrometers thick sections were stained with hematoxylin and eosin (HE) and Van Gieson. Micrographs were obtained in a Zeiss Axiophot brightfield microscope. For the comparative study of the microscopic alterations observed in the case of coinfection of $H$. isolonche and $H$. gallinarum in C. pictus, original slides CHIOC $19502 \mathrm{a}$-g, were examined.

The development of this research has been authorized by the Committee of Ethics for the Use of Animals (CEUA-Fiocruz), P0095-01.

\section{RESULTS}

The prevalence of $H$. gallinarum (Fig. 1a) was $90 \%$, with a mean intensity of 81.9 and range of infection of 1413. The nematodes were observed along the whole length of the caeca, mainly in the tips of these organs, in all the investigated localities. The nematode $H$. isolonche was not found and the parasitized birds with $H$. gallinarum did not present clinical signs.

The gross lesions in the caeca, present in $37(82 \%)$ of parasitized pheasants, were characterized by congestion, thickening, and petechial haemorrhages in the mucosa, intussusception in one of the birds, abscesses in the cecal tips of two birds, and nodules projecting in the mucosa and serosa. These birds presented a mean infection of 74.0 and a range of infection of 1-413. In 18 (40\%) of the parasitized birds, 1-10/cecum small pink, dark-brown or reddish nodules, $1-3 \mathrm{~mm}$ in diameter projecting in the mucosa, with or without central openings were observed (Fig. 1d). The mean infection and range of infection in these animals were 41.8 and 1-193, respectively. In another $8(17 \%)$ infected pheasants, for which these values were 111.4 and 5-310, light-pink, dark-brown or orange-reddish nodules also were present. Nevertheless, these lesions $1-25 /$ cecum were bigger, 5-8 $\mathrm{mm}$ in diameter, without central opening, mainly projecting in the mucosa but also appearing in the serosa (Fig. 1b, c); when sectioned the nodules were white-grayish in color.

The microscopic lesions in the parasitized ring-necked pheasants were diffuse chronic typhlitis with mononuclear cells infiltrate, haemosiderosis in the lamina propria and nodules in the mucosa, submucosa, and serosa. The 1-3 $\mathrm{mm}$ diameter nodules were localized in the submucosa and were represented by granulomas centralized with necrotic material suggesting the passage of helminth larvae and, in one out of two pheasants, were associated with lymphoid leucosis. The 5-8 mm diameter nodules appeared under several aspects; the smallest, compact and of fibrovascular nature, were located in the submucosa and muscular layer, projecting into the serosa. The biggest, of similar aspect, were present in the submucosa, and presented areas of myxoid characteristics with linear lymphocyte infiltrates. Multinuclear giant cells and histiocytes surrounded fragments of immature worms and cellular debris. Some of these nodules, covered with fibrotic tissue, were mainly located in the submucosa but also in the muscular layer and seldom in the serosa, showing characteristics of neoplasia, with fusiform oncocytes, with rounded to ovaled nuclei, forming bundles and whorls, without signs of atypical cells or invasion of adjacent tissues (Fig. 2a, b, c). Frequently, immature worms, some in a process of degeneration, surrounded by necrosis, were observed in cross-sections of these nodules (Fig. 2a, b). The staining by the Van Gieson's technique revealed, in despite of the discreet affinity to the stain, the presence of a leiomyoma. The mucosa in the site of the lesion showed the presence of a rich mononuclear infiltrate, erosion areas and marked atrophy (Fig. 2a). In the case of the intussusception, erosion of the caecal epithelial lining and predominant mononuclear infiltrates with few granulocytes in the mucosa, haemorrhagic areas in the lamina propria, a large edema in the submucosa and serositis were observed.

Examination of slides CHIOC $19502 \mathrm{a}$-g containing the cross-sections of the caeca of $C$. pictus parasitized with $H$. gallinarum and $H$. isolonche in accordance with Mendonça (1953) revealed a great amount of viable worms, almost adults, mainly localized in the submucosa (Fig. 2d). The inflammatory reaction was absent around some of the parasites. Nevertheless, necrotic areas with cholesterol clefts in the submucosa (Fig. 2e) and giant cell granulomas in the submucosa and serosa, centralized by necrosis and sections of nematodes could be observed (Fig. 2f). Also, neoplastic nodules in the submucosa and muscular layer identical to those observed in our material could be seen. However, a more specific classification of the neoplasia could not be achieved by means of special staining methods, since the slides were prepared with hematoxylin and eosin and paraffin blocks were not available.

\section{DISCUSSION}

The high prevalence, mean intensity, and range of infection of $H$. gallinarum observed indicate that this is a very common nematode species infecting backyard flocks of ring-necked pheasants in the state of Rio de Janeiro. In this same locality this parasite was also the most frequent and highly prevalent $(100 \%)$ in guinea fowls (Menezes et al. 2001) and (60\%) in domestic chickens (Grisi \& Carvalho 1974). H. gallinarum was also the most prevalent parasite recorded from ring-necked pheasants in England (Draycott et al. 2000), US (Olsen 1938, Gilbertson \& Huggins 1964, Greiner 1972, Pence et al. 1980), and Denmark (Madsen 1941). 
The absence of $H$. isolonche, reported only once in Brazil by Mendonça (1953) suggests that this may be an exotic parasite in our country. That case report referred above was on the basis of nematodes recovered from presumably imported birds, and historical data, shows that the birds were already parasitized on arrival in Rio de Janeiro, (departing from the state of São Paulo), reinforces this argument.

In the scarce papers that refer to the frequency of $H$. isolonche in pheasants, Clapham (1961) reported a low
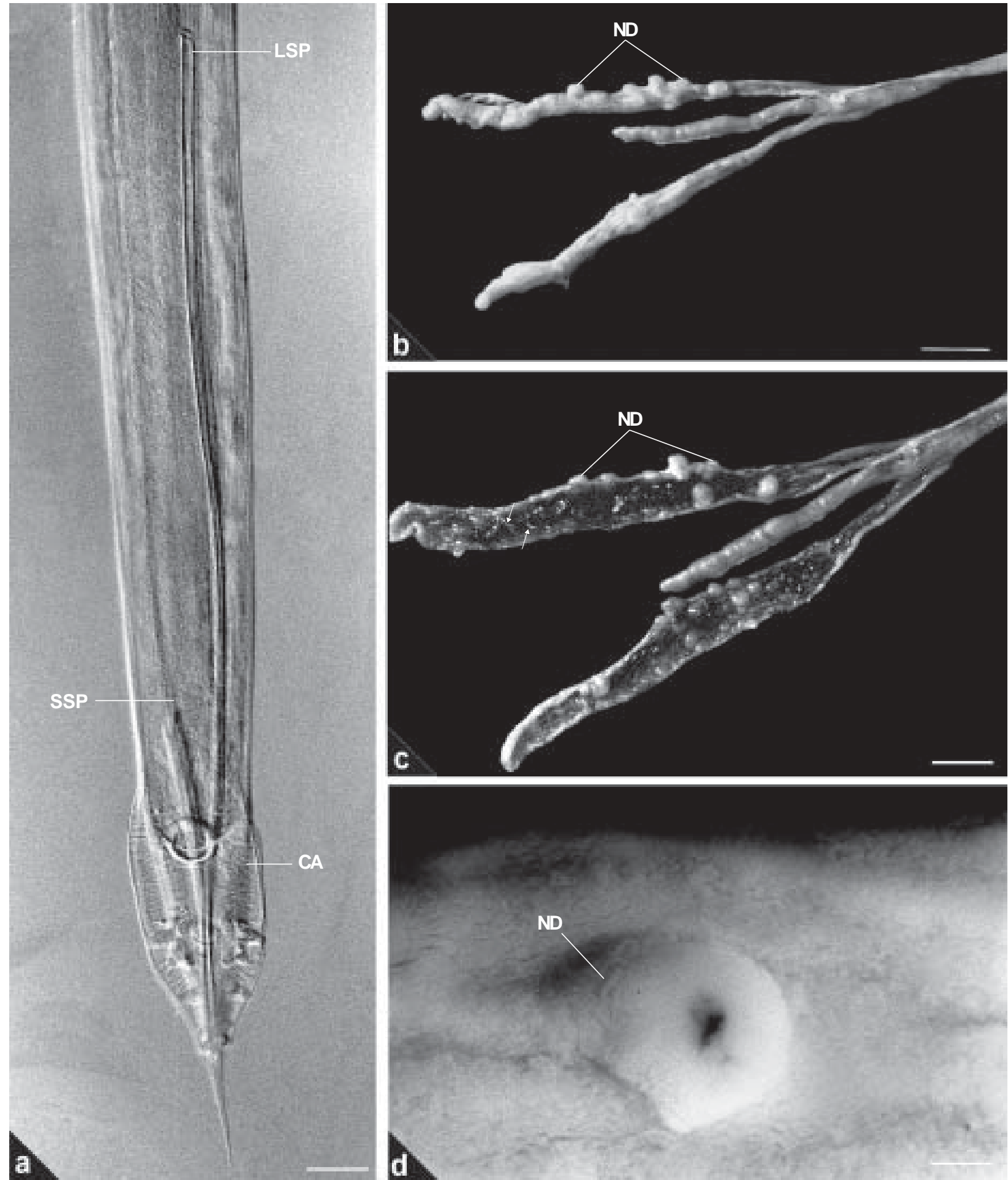

Fig. 1a-d - Heterakis gallinarum. a: posterior region of an adult male worm showing the smaller spicule (SSP), longer spicule (LSP), and caudal alae $(\mathrm{CA})$, bar $=0.03 \mathrm{~mm}$; b: multiple neoplastic cecal nodules $(\mathrm{ND})$ projecting in the serosa, bar $=20 \mathrm{~mm}$; c: specimens $($ arrows) in the cecal lumen and multiple neoplastic nodules (ND) projecting in the mucosa, bar $=13.8 \mathrm{~mm}$; d: granulomatous nodule with a central opening projecting in the cecal mucosa, bar $=1 \mathrm{~mm}$ 
prevalence $(7.9 \%)$ in the United Kingdom, and Dowel et al. (1983) found this nematode in only $1.2 \%$ of the pheasants investigated. However, higher prevalences of $H$. isolonche have been reported in other birds, such as the bowhite quail (Colinus virginianus), and the lesser prairie chicken (Tympanucus pallidicinctus) in the US (Pence et al. 1983, Moore et al. 1986), and scavenging chickens in Africa (Permin et al. 1997, Poulsen et al. 2000), but with rather lower values than those observed for $H$. gallinarum when present.

The cecal gross lesions associated with $H$. gallinarum in the present study were not always related to heavy worm burdens. These were similar burdens to those described for guinea fowls by Menezes et al. (2001) and in domestic chickens by León and Soldevila (1978). However, these authors did not refer to the occurrence of cecal
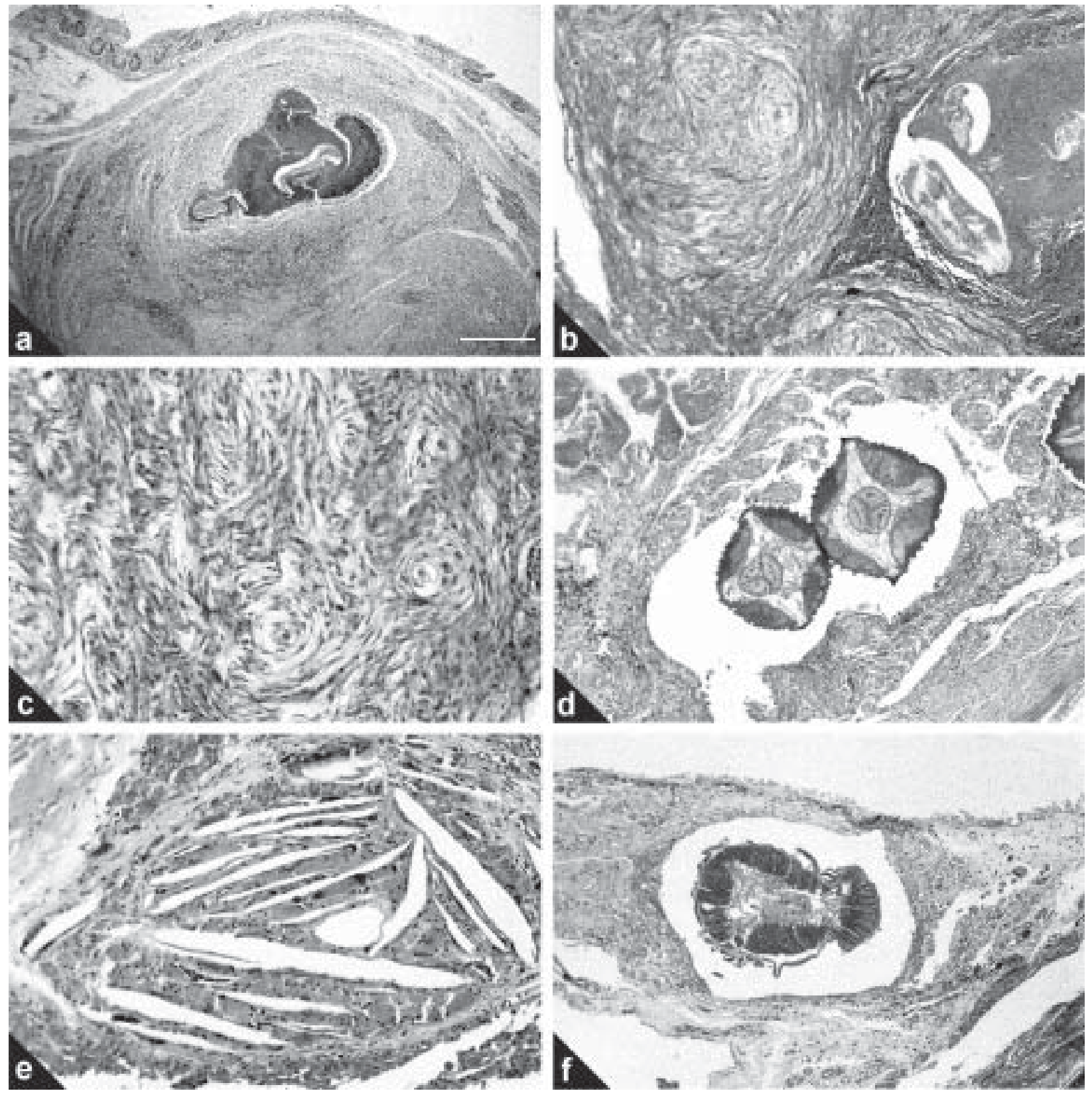

Fig. 2a-f - Micrographs of histological sections of caeca of Phasianus colchicus and Chrysolophus pictus parasitized with Heterakis spp. stained with hematoxylin-eosin, scale bar is common to all figures; a-c: cross-sections of the caeca of $P$. colchicus parasitized with Heterakis gallinarum; a: leiomyoma centralized by sections of $H$. gallinarum larvae and necrosis surrounded by histiocytes, bar $=0.26 \mathrm{~mm}$; b: leiomyoma showing neoplastic smooth muscle arranged in whorls and interlacing bundles surrounding mononuclear infiltrate, necrosis and sections of imature nematodes, $b a r=0.12 \mathrm{~mm}$; c: leiomyoma composed by fusiform oncocytes with round and oval nuclei arranged in whorls and interlacing bundles, bar $=0.07 \mathrm{~mm}$; d-f: cross-sections of the caeca of a C. pictus parasitized with $H$. isolonche and $H$. gallinarum; d: neoplastic nodule surrounding helminth sections in the submucosa layer, bar $=0.12 \mathrm{~mm}$; e: necrotic area with cholesterol clefts in the submucosa, bar $=0.06 \mathrm{~mm}$; f: granuloma with multinucleate giant cells surrounding sections of Heterakis sp. in the serosa, bar $=0.12 \mathrm{~mm}$ 
nodules. Such nodules were noted by Khan et al. (1994), in guinea fowls, Kaushik and Sharma Deorani (1969), Mutalib and Riddell (1982), Riddell and Gajadhar (1988) in domestic chickens, and Meads and Taylor (1963) in pheasants, microscopically classified as inflammatory (Meads \& Taylor 1963, Kaushik \& Sharma Deorani 1969) or granulomas (Mutalib \& Riddell 1982, Riddell \& Gajadhar 1988, Khan et al. 1994), associated with the presence of $H$. gallinarum, as observed in this study. Helmboldt and Wyand (1972) reported the occurrence of neoplastic nodules in the golden pheasant, identified to leiomyomas caused by immature specimens of Heterakis sp., in despite of finding only $H$. gallinarum in the cecal lumen. Taking into account that the results of these authors were similar those obtained here, it can be affirmed that the leiomyomas were due to $H$. gallinarum infection alone, because if specimens of $H$. isolonche were present, then adult nematodes of this species would have been observed in the lumen or burrowed in the cecal submucosa of the parasitized birds, their principal site of infection (Schwartz 1924, Griner et al. 1977).

The cecal nodules associated with $H$. isolonche, mainly in the submucosa, have already been microscopically classified as granulomas and fibrous hyperplastic tissue (Griner at al. 1977, Callinan 1987), of fibrohistiocytic nature (AFIP 1998) or fibrovascular (Julini \& Valenza 1975) and leiomyoma (Krahnert 1952, Balaguer et al. 1992), demonstrating controversial diagnoses. These descriptions are similar to the nodules observed in this study having, as a common characteristic, formation by fusiform mesenchymal cells with elongate nuclei arranged in dense whorls and interlacing bundles, sarcomatous in aspect, but without metastasis, mitotic figures or infiltrations. On the basis of these characteristics, showing a situation of uncontrolled cell proliferation and in accordance with the definition of neoplasia (Jones et al. 1997), the nodules observed herein can be considered benign neoplasms, in disagreement with Julini and Valenza (1975), Griner et al. (1977), Callinan (1987), and AFIP (1998).

A question to be answered is why leiomyomas were found in only eight of the pheasants parasitized with $H$. gallinarum, some with small worm burdens. In line with the present results, and those previously reported, the development of this neoplasia could be related to the immune response of pheasants to parasitism by Heterakis sp. The species $H$. isolonche, due to its higher pathogenicity related to its histotropic cycle (Levine 1980), would be the more frequent etiological agent of the neoplasia; nevertheless, the presence of immature $H$. gallinarum worms would be also responsible for the formation of tumors.

The microscopic lesions present in the slides of Mendonça (1953) were more severe than those observed here, possibly due to the larger amount of more developed worms perforating the cecal wall and provoking peritonitis, the probable cause of death of the pheasants. It was impossible to relate the nodular lesions to specimens of $H$. isolonche alone, in despite of the stage of development of these helminths, since their association with $H$. gallinarum worms was observed.
We agree with Riddell and Gajadhar (1988) in considering that the probable causes for the appearance of granulomatous nodules, that in our opinion could evolve to neoplasias, would be continuous reinfections with $H$. gallinarum provoking a tissular phase for the parasite as observed by Kaushik and Sharma Deorani (1969), mainly by infections with different strains of nematode harbored by other host species. These strains are likely not adapted to the ring-necked pheasant, and thus induce a higher pathogenicity, as shown in previous results. Tompkins et al. (2001) in experimental infections of ring-necked pheasants and grey partridge (Perdix perdix), using $H$. gallinarum recovered from pheasants demonstrated that the latter hosts were more severely affected, in terms of weight, reduction of food intake and decrease of cecal activity. Perhaps related to this, strains of $H$. gallinarum from chickens were not so successful (in terms of the number of adult worms recovered, and the fecundity of females) when inoculated into turkeys (Lund et al. 1970). In addition, in young chuckar partridges, larvae strains of H. gallinarum recovered from other domestic Galliformes, and thus not physiologically adapted to this host, frequently perforate the cecal wall causing peritonitis (Lund \& Chute 1974). Hence, the obtained results suggest a general pattern whereby both parasite fitness and host pathology can be observed.

\section{ACKNOWLEDGEMENTS}

To Jayade Machado de Mendonça, retired researcher of the Departamento de Helmintologia, Instituto Oswaldo Cruz, who pioneered the study of the nodular typhlitis of pheasants in Brazil 50 years ago, and to Bruno Eschenazi Vieira, Laboratório de Imagens, Instituto Oswaldo Cruz, for technical assistance with the figures.

\section{REFERENCES}

AFIP-Armed Forces Institute of Pathology 1998. AFIP Wednesday Slide Conference-No.15. http://www.afip.org/ vetpath/WSC/WSC97/97wsc15.htm.

Balaguer L, Romano J, Nieto JM, Fernandez JP 1992. Nodular typhlitis of pheasants caused by Heterakis isolonche: further evidence of a neoplastic nature. J Zoo Wildl Med 23: 249- 253.

Beaudette FR 1942. Heterakis isolonche Linstow (1906) in a pheasant with remarks on tuberculosis and gapeworms. J Am Vet Med Assoc 101: 274-275.

Behmer OA, Tolosa EMC, Freitas-Neto AG 1976. Manual de Técnicas para Histologia Normal e Patológica, Edart, São Paulo, $256 \mathrm{pp}$.

Bhaskara Rao P 1994. Heterakiasis in a golden pheasant (Chrysolophus pictus). Indian Vet J 71: 516.

Callinan RB 1987. Nodular typhlitis in pheasants caused by Heterakis isolonche. Aust Vet J 64: 58-59.

Clapham PA 1961. Recent observations on helminthiasis in some British game birds. J Helminthol (R.T. Leiper Suppl.): $35-40$

Dowell JH, Warren RJ, Pence DB 1983. Helminth fauna of ring-necked pheasants from the Texas High Plains. $J$ Wildl Dis 19: 152-153.

Draycott RAH, Parish DMB, Woodburn MIA, Carroll JP 2000. Spring survey of the parasite Heterakis gallinarum in wild living pheasants in Britain. Vet Rec 147: 245-246.

Gilbertson DE, Hugghins EJ 1964. Helminth infections in 
pheasants from Brown County, South Dakota. J Wildl Manage 28: 543-546.

Greiner EC 1972. Parasites of Nebraska pheasants. $J$ Wildl Dis 8: 203-206.

Griner LA, Migaki G, Penner LR, McKee Jr AE 1977. Heterakidosis and nodular granulomas caused by Heterakis isolonche in the ceca of gallinaceous birds. Vet Pathol 14: $582-590$.

Grisi L, Carvalho LP 1974. Prevalência de helmintos parasitos de Gallus gallus domesticus L., no estado do Rio de Janeiro. Rev Bras Biol 34: 115-118.

Helmboldt CF, Wyand DS 1972. Parasitic neoplasia in the golden pheasant. $J$ Wildl Dis 8: 3-6.

Jones TC, Hunt RD, King NW 1997. Veterinary Pathology, 6th ed., Williams \& Wilkins, Massachusetts, 1392 pp.

Julini M, Valenza F 1975. Sulla tiflite verrucosa da Heterakis isolonche nel fagiano. Clin Vet 98: 269-278.

Kaushik RK, Sharma Deorani VP 1969. Studies on tissue responses in primary and subsequent infections with Heterakis gallinae in chickens and on the process of formation of caecal nodules. J Helminthol 43: 69-78.

Khan SA, Iqbal M, Ashraf SK 1994. Occurrence and pathology of cecal granuloma in guinea fowl (Numida meleagris) associated with Heterakis gallinarum infection. Int J Anim Sci 9: 143-145.

Krahnert R 1952. Sarkoides Leyomyom nach Heterakidenbefall. Monatshf Veterinaermed 7: 71-75.

León D, Soldevila M 1978. Capillaria annulata and Heterakis gallinarum infections in guinea fowl in Puerto Rico - A case report. J Agric Univ Puerto Rico 62: 428-430.

Levine ND 1980. Nematode Parasites of Domestic Animals and Man, 2nd ed., Burgess Publishing, Minneapolis, 479 pp.

Lund EE, Chute AM 1974. The reproductive potential of Heterakis gallinarum in various species of galliform birds: implications for survival of $H$. gallinarum and Histomonas meleagridis to recent times. Int J Parasitol 4: 455-461.

Lund EE, Chute AM, Myers, SL 1970. Performance in chicken and turkeys of chicken adapted Heterakis gallinarum. $J$ Helminthol 44: 97-106.

Madsen H 1941. The occurrence of helminths and coccidia in partridges and pheasants in Denmark. J Parasitol 27: 2934.

Meads EB, Taylor PA 1963. Typhlitis in pheasants due to Heterakis gallinae. Can Vet J 4: 56-59.

Mendonça JM 1953. Heterakis isolonche Linstow, 1906 e Heterakis gallinae (Gmelin, 1790), agentes causais da tiflite verrucosa em faisões no Jardim Zoológico do Distrito Federal. Mem Inst Oswaldo Cruz, 51: 675-687.
Menezes RC, Mattos Jr DG, Tortelly R 2001. Freqüência e patologia das infecções causadas por nematóides e cestóides em galinhas-d' angola (Numida meleagris Linnaeus, 1758) criadas extensivamente no estado do Rio de Janeiro, Brasil. Rev Bras Cienc Vet 8: 35-39.

Moore J, Freehling M, Simberloff D 1986. Gastrointestinal helminths of the northern bobwhite in Florida: 1968 and 1983. J Wildl Dis 22: 497-501.

Mutalib AA, Riddell C 1982. Cecal and hepatic granulomas of unknown etiology in chickens. Avian Dis 26: 732-740.

Olsen OW 1938. Parasite studies on ring-necked pheasants, Phasianus colchicus torquatus (Gmelin) in Minnesota. J Parasitol 24: 24-25.

Pence DB, Murphy JT, Guthery FS, Doerr TB 1983. Indications of seasonal variation in the helminth fauna of the lesser prairie chicken, Tympanuchus pallidicinctus (Ridgway) (Tetraonidae), from northwestern Texas. Proc Helminthol Soc Wash 50: 345-347.

Pence DB, Young VE, Guthery FS 1980. Helminths of the ringnecked pheasant, Phasianus colchicus (Gmelin) (Phasianidae), from the Texas Panhandle. Proc Helminthol Soc Wash 47: 144-147.

Permin A, Magwisha H, Kassuku AA, Nansen P, Bisgaard M, Frandsen F, Gibbons L 1997. A cross-sectional study of helminths in rural scavenging poultry in Tanzania in relation to season and climate. J Helminthol 71: 233-240.

Poulsen J, Permin A, Hindsbo O, Yelifari L, Nansen P, Bloch P 2000. Prevalence and distribution of gastro-intestinal helminths and haemoparasites in young scavenging chickens in upper eastern region of Ghana, West Africa. Prev Vet Med 45: 237-245.

Riddell C, Gajadhar A 1988. Cecal and hepatic granulomas in chickens associated with Heterakis gallinarum infection. Avian Dis 32: 836-838.

Schwartz B 1924. Occurrence of nodular typhlitis in pheasants due to Heterakis isolonche in North America. J Am Vet Med Assoc 65: 622-625.

Tompkins DM, Greenman JV, Hudson PJ 2001. Differential impact of a shared nematode parasite on two gamebird hosts: implications for apparent competition. Parasitology 122: 187-193.

Vicente JJ, Rodrigues HO, Gomes DC, Pinto RM 1995. Nematóides do Brasil. Parte IV: Nematóides de aves. Rev bras Zool 12: 1-273.

Zander DV, Bermudez AJ, Mallinson ET 1997. Principles of disease prevention: diagnosis and control. In BW Calnek, HJ Barnes, CW Beard, LR McDougald, YM Saif (eds), Diseases of Poultry, 10th ed., Iowa State University Press, Ames, p. 3-45. 